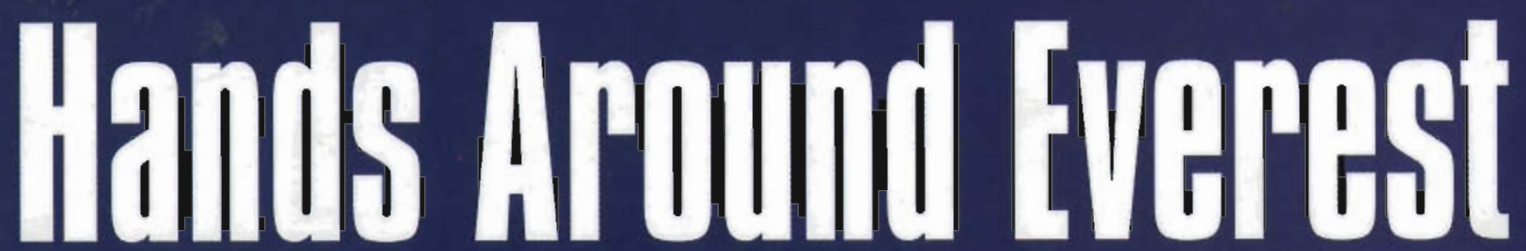

Transboundary Cooperation for Conservation and Sustainable Livelihoods

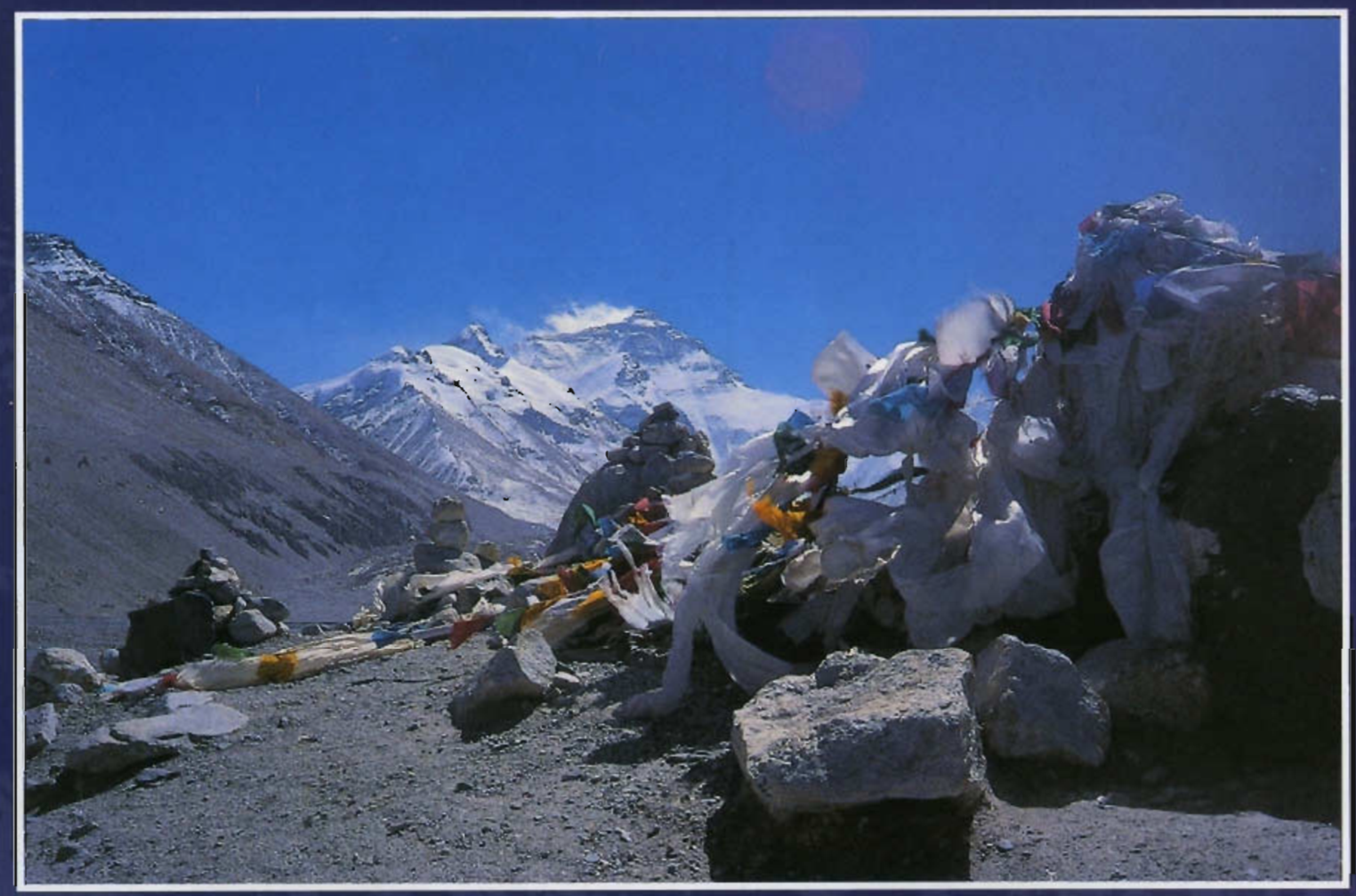

Lhakpa Norbu Sherpa

Brian Peniston

Wendy Lama

Camille Richard

Compiled by

Frances Klatzel

Kate Hoffman 

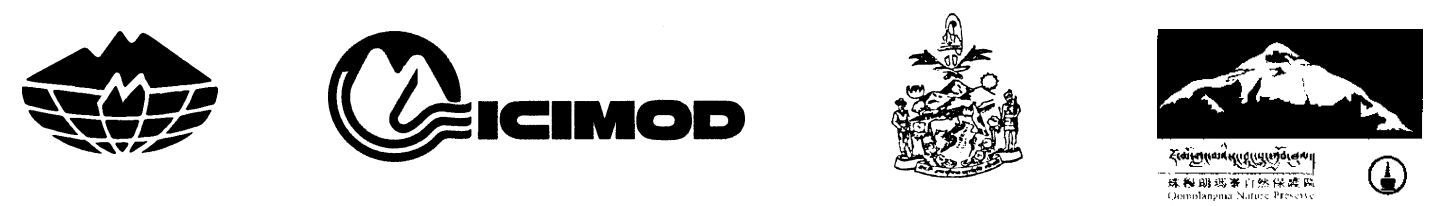

\title{
HANDS AROUND EVEREST \\ Transboundary Cooperation for Conservation and Sustainable Livelihoods
}

\author{
Lhakpa Norbu Sherpa \\ Brian Peniston \\ Wendy Lama \\ Camille Richard
}

compiled by

Frances Klatzel

Kate Hoffman

\section{Cooperating Organisations}

The Mountain Institute (TMI)

International Centre for Integrated Mountain Development (ICIMOD)

Department of National Parks and Wildlife, Nepal

Qomolangma Nature Preserve, Tibet Autonomous Region, China 
Copyright () 2003

International Centre for Integrated Mountain Development The Mountain Institute

All rights reserved

\section{Cover Plate}

Mount Everest, Brian Peniston

ISBN: 9291157031

\section{Published by}

International Centre for Integrated Mountain Development GPO Box 3226, Kathmandu, Nepal

\section{ICIMOD Editorial Team}

A. Beatrice Murray (Editor)

Sushil Man Joshi (Technical Support and Layout)

\section{Printed and bound in Nepal by}

The views and interpretations in this paper are those of the author(s). They are not attributable to the International Centre for Integrated Mountain Development (ICIMOD) or The Mountain Institute (TMI) and do not imply the expression of any opinion concerning the legal status of any country, territory, city or area of its authorities, or concerning the delimitation of its frontiers or boundaries. 
It is passible that the lest ideas for the future may come not from professionals who try to speak on behalf of mountains, but from mountain peoples themselves who speak for themselves.

- Robert Rhoades - 


\section{Foreword}

Regional cooperation in the Hindu Kush-Himalayan $(\mathrm{HKH})$ Region is receiving greater attention as nations increasingly recognize that the environmental security and social welfare of mountain people depend upon the management of resources across political borders. Species and communities of plants and animals are not limited by political boundaries and landscapes and ecosystems existed long before national jurisdictions. About 65 countries have developed different strategies to conserve their transboundary resources.

The Mt. Everest region is one such important transboudary landscape. Four contiguous protected areas link hands around Mt. Everest: Qomolangma Nature Preserve in Tibet; and Sagarmatha National Park, Makalu - Barun National Park, and Langtang National Park in Nepal, conserving a large, continuous ecosystem and the rich cultural and natural heritage on both sides of the Himalaya. They jointly cover nearly 40,000 square km, an area large enough for maintaining species, communities, and ecological processes. Reconciling the needs of the local communities with conserving ecosystems and biotic diversity, has become a major challenge facing the managers of these protected areas.

Beginning in 1995, ICIMOD started the Regional Collaborative Programme on Biodiversity Management in partnership with regional member countries of the HKH Region. One of the programme activities initiated and supported by a series of grants from the John D. and Catherine T. MacArthur Foundation and continuing to this day as part of its new strategic plan for 2003.7 is to promote transboundary cooperation for biodiversity management. Successful exchanges and discussions have provided greater options for further collaboration among countries in the region.

The Mountain Institute (TMI), an international NGO based in West Virginia, U.S.A. and the Governments of Nepal and China, have conducted discussions, activities and exchanges since 1986 to promote transboundary collaboration, applied research, and participatory management in biodiversity and cultural conservation in the Mt. Everest region. Since 1994, The Mountain Institute's Transboundary Biodiversity Conservation in the Himalaya 
program has also been supported by a grant from the John D. and Catherine T. MacArthur Foundation. Its activities have focused on collaborative planning and management with Protected Area managers, and promotion of economic incentives for conservation initiatives and collaboration.

Recognizing a common goal, to ensure long-term protection of the unique biological and cultural resources of the Himalayan region, and capitalizing on each organization's comparative advantages, ICIMOD and TMI began a collaborative programme in 1998. Since that time, the two organizations have jointly supported transboundary exchanges, site-specific research activities along the border, and production of conservation education materials for transboundary communities.

ICIMOD is extremely grateful for the opportunity to work in such close partnership with TMI. The John D. and Catherine T. MacArthur Foundation has made this collaboration possible by supporting both organizations with a focus on the Central Himalayan region, which includes the Everest region. I hope that this summary of five years of joint efforts provides a valuable platform for future transboundary negotiations among the neighboring countries of Nepal and China, culminating in the protection and conservation of the biological and cultural heritage of the Mt. Everest ecosystem.

J. Gabriel Campbell

Director General, ICIMOD 


\section{Acknowledgements}

Thanks are due to the John D. and Catherine T. McArthur Foundation for funding support, TMI and ICIMOD for their catalytic role in promoting transboundary cooperation, Mountain Spirit, a Nepali NGO, for providing valuable technical support, the Department of National Parks and Wildlife Conservation and the Working Commission for the Qomolangma Nature Preserve, TAR, for their participation and support. This publication is a synthesis of a series of reports and activities in which many people participated. Special recognition is given to the contributions of Lhamu Sherpa, Lhakpa Tenzing Sherpa and Tsedan Drogar from QNP WC. We are also very grateful to the many others involved, too numerous to mention by name. Finally, and most importantly, we thank the local people of the border regions of Tibet and Nepal for freely sharing their feelings about transboundary issues affecting their environment, economy, and culture. 


\section{Executive Summary}

Ecosystems existed long before national jurisdictions, and species and communities of plants and animals are not limited by political boundaries and landscapes. Hence, many countries share biological and natural resources across their borders that to be managed properly require cooperation. One very important transboundary ecosystem is that of the Mt. Everest Himalayas along the border between Nepal and the Tibet Autonomous Region (TAR) of China. This region encompasses an enormous variation in altitude within a short distance and contains an incredible range of landscape types and a rich diversity of plant and animal species. Furthermore, as the location of the head waters of Asia, the Himalayas both link the two countries and take on major significance for many people downstream.

Efforts towards transboundary cooperation for conservation in the Mount Everest region started nearly twenty years ago and progress since then has been slow but steady. This publication summarises activities in an innovative programme started in 1994/1995 by The Mountain Institute (TMI), the International Centre for Integrated Mountain Development (ICIMOD), and the Governments of Nepal and China, under TMI's 'Transboundary Biodiversity Conservation in the Eastern Himalayas Programme' and ICIMOD's 'Programme on Regional Collaboration for Biodiversity Management in the Eastern Himalayas', both funded by the MacArthur Foundation. These programmes, separately and together, have supported a series of discussions and exchange activities among protected area managers, scientists, and local people involving four contiguous protected areas around Mt. Everest - Qomolangma Nature Preserve in TAR, China, and Sagarmatha, Makalu-Barun, and Langtang National Parks in Nepal - and the Kangchenjunga Conservation Area in Nepal. The focus in this book is on the four areas around Mt. Everest, which together conserve a large, continuous ecosystem and rich cultural and natural heritages on both sides of the Himalayas. They cover nearly 40,000 sq. km, an area large enough to maintain species, communities, and ecological processes.

The isolated villages in these protected areas are home to more than 110,000 people who share a common cultural heritage. Reconciling the needs of these local communities with conservation of ecosystems and biodiversity has become a major challenge facing the managers of these protected areas. The protected area managers feel that effective biodiversity 
conservation requires active support from the local people, who can be motivated by improving their livelihoods. Though villagers claim that there has been a general improvement in the local economy, more emphasis is needed on opening tourism opportunities and cross-border trade, and on providing education and training for local people.

Park managers identified four key issues on which cooperation was needed: poaching and smuggling of wildlife products, cross-border spread of livestock disease, cross-border spread of forest fires, and livelihoods of people near the border. These four issues were endorsed by a meeting of ministry level and line agency representatives, who formalised the transboundary cooperation efforts and also agreed five specific areas of cooperation. In 1999, a joint study team from Nepal and TAR travelled to five selected villages located along the border and conducted participatory meetings with local villagers on transboundary issues. They presented the outcomes of the village meetings to representatives of relevant government agencies. In general, the concept of transboundary cooperation across the border received strong local support and interest, despite several logistical challenges.

Subsequent transboundary exchanges have strengthened relationships among professionals from both sides of the border and have started to address specific livelihood issues identified in village meetings. The expertise of TMI in ecotourism led to a focus on conservation and ecotourism in some of the exchanges. Follow-up programmes were suggested to strengthen linkages and to address the four main cross-border issues.

This document gives a brief background of the transboundary region and a history of relationships and joint activities between Nepal and TAR, China, related to this area. The various exchanges that have taken place are summarised, and the major characteristics of the villages included in the survey are described, together with the aspirations of the villagers. The situation and progress made on the four key issues are discussed in detail, with sections on problems and possible solutions, and suggestions for future action. The document ends with a discussion of achievements and constraints in cross-border development, and sections giving recommendations for the future and suggestions for immediate action.

The main recommendation was to consolidate and expand transboundary activities: specifically by consolidating and regularising the interaction and communication of protected area professionals and managers; following up on the recommendations for activities at the community level, especially by using existing forums such as annual herders' meetings; promoting joint World Heritage Site designation for QNP; expanding the transboundary activities to contiguous valleys that are not included in protected areas; and expanding transboundary cooperation beyond QNP to include other protected areas of TAR.

Immediate activities that were suggested included offering incentives for information on poaching activities; training in the identification of species that are traded illegally; providing veterinary services for livestock in two villages; conducting a workshop on forest fire management; and preparing a proposal for joint World Heritage Status for QNP. 


$\begin{array}{ll}\text { Al } & \text { appreciative inquiry } \\ \text { APP } & \text { Agriculture Perspective Plan } \\ \text { CBO } & \text { community-based organisation } \\ \text { CITES } & \text { Convention on Illegal Trade in Endangered Species } \\ \text { DC } & \text { District of Columbia (USA) } \\ \text { DNPWC } & \text { Department of National Parks and Wildlife Conservation (Nepal) } \\ \text { ECA } & \text { environment conservation area } \\ \text { FMD } & \text { foot-and-mouth disease } \\ \text { HKH } & \text { Hindu-Kush Himalayas } \\ \text { HMG } & \text { His Majesty's Government (Nepal) } \\ \text { ICIMOD } & \text { International Centre for Integrated Mountain Development } \\ \text { IDRC } & \text { International Development Research Council } \\ \text { LNP } & \text { Langtang National Park } \\ \text { MBNP } & \text { Makalu-Barun National Park } \\ \text { Mt. } & \text { Mount } \\ \text { NGO } & \text { non-government organisation } \\ \text { NTFP } & \text { non-timber forest product } \\ \text { PRA } & \text { participatory rural appraisal } \\ \text { PRC } & \text { People's Republic of China } \\ \text { QCP } & \text { Qomolangma Conservation Programme } \\ \text { QNP } & \text { Qomolangma Nature Preserve } \\ \text { RRA } & \text { rapid rural appraisal } \\ \text { SNP } & \text { Sagarmatha National Park } \\ \text { TAR } & \text { Tibet Autonomous Region } \\ \text { TMI } & \text { The Mountain Institute } \\ \text { UNDP } & \text { United Nations Development Programme } \\ \text { USA } & \text { United States of America } \\ \text { VDC } & \text { village development committee } \\ \text { WWF } & \text { World Wide Fund for Nature Conservation } \\ & \end{array}$




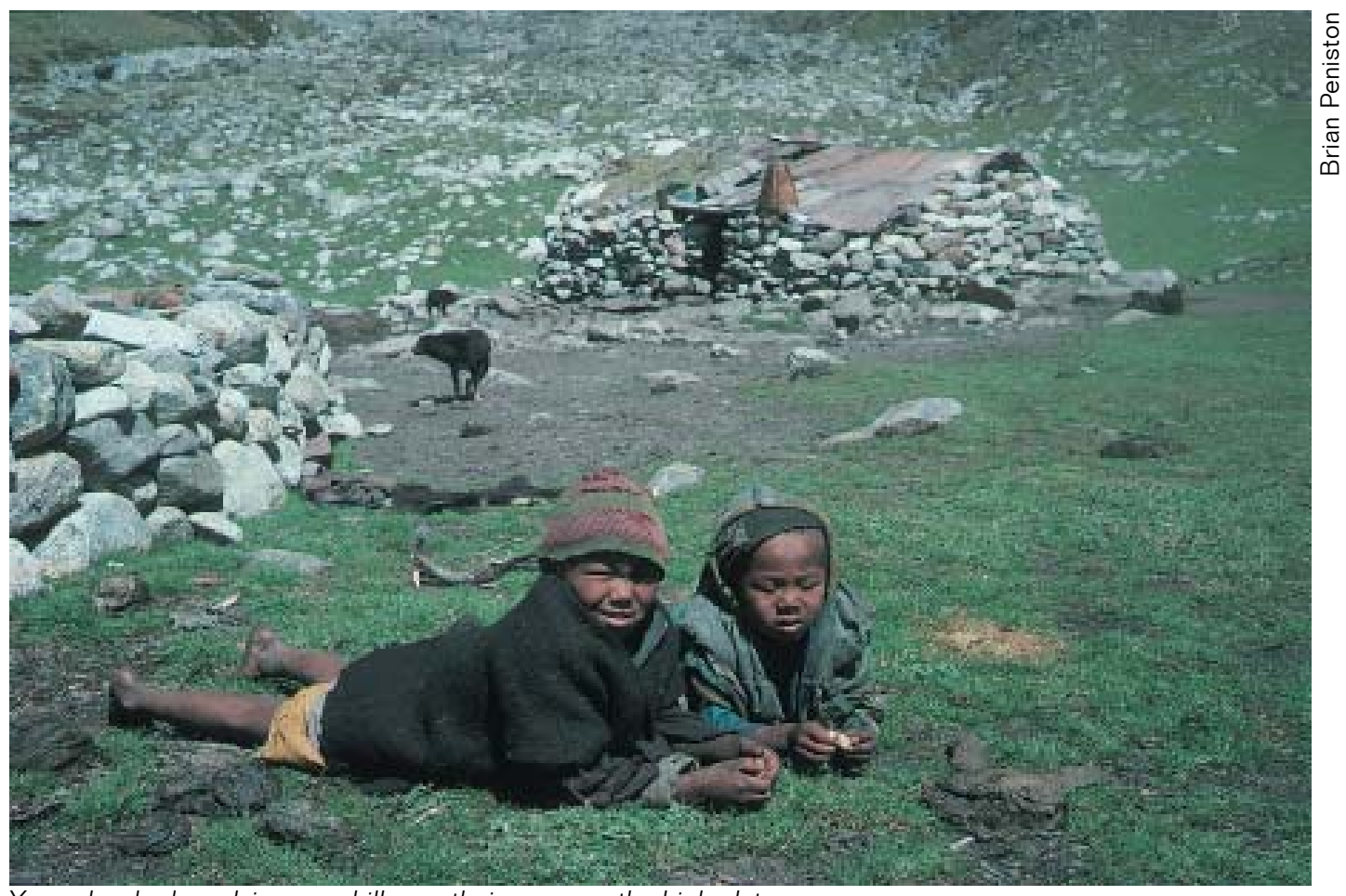

Young herder boys lying on a hill near their camp on the high plateau 


\section{Table of Contents}

Foreword

Acknowledgements

Executive Summary

Abbreviations and Acronyms

1 Transboundary Issues in the Mount Everest Ecosystem 1

An Open Boundary 1

Transboundary Cooperation in the Mt. Everest Ecosystem 10

2 Villages of the Transboundary Region $\quad 21$

The Joint Study 21

The study approach $\quad 24$

The study villages $\quad 25$

3 The Four Main Transboundary Issues $\quad 39$

Illegal Poaching and Trade in Endangered Species 39

Cross-border Spread of Forest Fires $\quad 47$

Cross-border Spread of Livestock Disease $\quad 51$

Improving Local Livelihoods 58

4 The Path Forward - Progress, Challenges, and Immediate Actions

$\begin{array}{ll}\text { for Conservation } & 67\end{array}$

$\begin{array}{ll}\text { Achievements and Cooperation Across the Himalayas } & 67\end{array}$

Challenges Hindering Transboundary Cooperation 70

Recommendations $\quad 71$

$\begin{array}{ll}\text { Bibliography } & 75\end{array}$

$\begin{array}{ll}\text { Annex: Legal Information } & 79\end{array}$ 